\title{
Association of STAT4 and PTPN22 polymorphisms and their interactions with type-1 autoimmune hepatitis susceptibility in Chinese Han children
}

\author{
Xiaofeng Li ${ }^{1}$, Huiqin Chen ${ }^{1}$, Yun Cai ${ }^{1}$, Pingping Zhang ${ }^{1}$ and Zhuanggui Chen ${ }^{1}$ \\ ${ }^{1}$ Department of Pediatrics, The Third Affiliated Hospital of Sun Yat-sen University, Guangzhou 510630, China \\ Correspondence to: Zhuanggui Chen, email: zhangsuqin3313@163.com \\ Keywords: autoimmune hepatitis, STAT4, PTPN22, single nucleotide polymorphism, interaction
}

Received: February 09, 2017

Accepted: April 12, 2017

Published: April 27, 2017

Copyright: Li et al. This is an open-access article distributed under the terms of the Creative Commons Attribution License 3.0 (CC BY 3.0 ), which permits unrestricted use, distribution, and reproduction in any medium, provided the original author and source are credited.

\section{ABSTRACT}

Aims: To investigate the impact of signal transducer and activator of transcription 4 (STAT4) and the protein tyrosine phosphatase N22 (PTPN22) gene single nucleotide polymorphisms (SNPs), gene-gene interactions and haplotype on type-1 Autoimmune Hepatitis (AIH) risk.

Results: Logistic regression analysis showed that type 1 AIH was significantly higher in carriers of $T$ allele of rs7574865 than those with GG genotype ( $P$ - value less than 0.001 ), higher in carriers of $C$ allele of rs7582694 than those with GG genotype $(P$ - value $<0.001)$, and lower in carriers of $T$ allele of rs2476601 than those with CC genotype $(P$-value $<0.001)$. GMDR model indicated a significant two-locus model $(p=$ 0.0100 ) involving rs7582694 and rs2476601. Participants with GC or CC of rs7582694 and CC of rs2476601 genotype have the highest type 1 AIH risk $(P$-value $<0.001$ ), after covariates adjustment. Haplotype containing the rs7582694-C and rs7574865-T alleles were associated with a statistically increased type 1 AIH risk $(P<0.001)$.

Materials and Methods: Logistic regression was performed to investigate association between SNPs within STAT4 and PTPN22 gene and susceptibility to type 1 AIH. Generalized multifactor dimensionality reduction (GMDR) was used to screen the best interaction combinations among the 4 SNPs.

Conclusions: We conclude that rs7574865 and rs7582694 in STAT4 gene minor alleles, interaction between rs7582694 and rs2476601, and haplotype containing the rs7582694-C and rs7574865-T alleles are associated with increased type 1 AIH risk, but rs2476601 in PTPN22 gene minor allele is associated with decreased type 1 AIH risk.

\section{INTRODUCTION}

Autoimmune hepatitis (AIH) was a kind of chronic inflammation of the liver, hypergammaglobulinemia and autoantibodies production [1]. A recent study in pediatric patients reported an incidence of 0.4 case per 100000 children [2]. Another study from Poland reported an incidence of 3 to 4 per 100000 children [3]. This disease displays female predominance and is considered rare in childhood, although it may occur in very young children [4]. The pathogenesis of AIH was not well known, but could be influenced by both genetic and environmental factors [5]. Mutations in the human leukocyte antigen (HLA) region have been reported associations with some types of autoimmune diseases, including AIH $[6,7]$.
Signal transducer and activator of transcription 4 (STAT4) gene has important role in dendritic cells and macrophages, activated peripheral blood monocytes [8]. The association between STAT4 and some autoimmune diseases, including rheumatoid arthritis (RA) or systemic lupus erythematosus (SLE) has been reported in several previous studies [9, 10], and in a mouse model, STAT4 is considered important of Th1-dependent liver injury [11]. A recent study suggested that STAT4 polymorphism was positively associated with type-1 AIH. rs2476601 in PTPN22 was a missense single nucleotide polymorphism (SNP), which has been more studied previously [12], and has been reported associations with some types of autoimmune diseases, including RA and SLE [12-15]. A Japanese population base study [16] indicated that 
PTPN22 SNPs play an important role in the genetic resistance to autoimmune liver disease. In consideration of the limited number of study on association between STAT4 and PTPN22 gene and AIH risk, particularly in Children. In this study, we aimed to investigate the impact of STAT4 and PTPN22 gene SNPs, additional gene-gene interaction and haplotype combination on type 1 AIH risk based on Chinese Han population.

\section{RESULTS}

A total of 542 participants (98 boys, 444 girls) consist of $180 \mathrm{AIH}$ patients and 362 normal participants were included in this study. The mean age of all participants is $8.1 \pm 3.9$ years. The clinical characteristics for cases and controls were shown in Table 1. The distribution of gender and the mean age were not significantly different between cases and controls. The mean of total Bilirubin was $3.87 \pm 4.14 \mathrm{mg} / \mathrm{ml}$, albumin was $3.89 \pm 0.75 \mathrm{~g} / \mathrm{L}$, the rate of SMA and cirrhosis at entry were $56.7 \%$ and 30.6 respectively.

All genotypes are distributed according to HWE in controls (all $p$ values are more than 0.05). The frequencies for rs7574865- $\mathrm{T}$ allele and rs7582694- C allele were significantly higher in type 1 AIH cases than control group (30.6\% vs $19.3 \%, 32.5 \%$ vs $20.0 \%$ ), and the frequencies for rs2476601- T allele was significantly lower in in type 1 AIH cases than control group (19.7\% vs30.0\%). Logistic regression analysis showed that type 1 AIH was significantly higher in carriers of $\mathrm{T}$ allele of rs7574865 than those with GG genotype (GT + TT versus GG), adjusted OR (95\% CI) = 1.63 (1.28-.98), and higher in carriers of $\mathrm{C}$ allele of rs 7582694 than those with GG genotype (GC + CC versus GG), adjusted OR $(95 \% \mathrm{CI})=1.73(1.38-2.19)$. In addition, we also found type 1 AIH risk was significantly lower in carriers of $\mathrm{T}$ allele of rs2476601 than those with $\mathrm{CC}$ genotype $(\mathrm{CT}+\mathrm{TT}$ versus CC), adjusted OR $(95 \% \mathrm{CI})=0.65$ (0.44-0.93). However, we did not find any significant association between rs2488457 and type 1 AIH risk after covariates adjustment. (Table 2).

GMDR were used to screen the best interaction combinations among 4 SNPs within STAT4 and PTPN22 gene on type 1 AIH risk (Table 3 ). We found that there is a significant two-locus model $(p=0.0100)$ involving rs7582694 and rs2476601. Overall, the cross-validation consistency of this two- locus model was 10/10, and the testing accuracy was $60.72 \%$. We also conducted stratified analysis for interaction between rs7582694 and rs2476601 by using logistic regression. We found that participants with GC or CC of rs7582694 and CC of rs2476601 genotype have the highest type 1 AIH risk, compared to participants with GG of rs7582694 and CT or TT of rs2476601 genotype, OR (95\% CI) = 3.12 (2.04-4.29), after covariates adjustment (Figure 1).

Pairwise LD analysis was performed between SNPs within the same gene, and $\mathrm{D}^{\prime}$ value between rs7582694 and rs7574865 was $0.831, \mathrm{D}^{\prime}$ value between rs2488457 and rs2476601was 0.761 . The most common haplotype in STAT4 gene was rs7582694-G and rs7574865-G haplotype, the frequencies of which were 0.4732 and 0.5547 in case group and control group, and the most common haplotype in PTPN22 gene was rs2488457- G and rs2476601-C haplotype, the frequency of which was 0.47893 and 0.4411 in case group and control group. Haplotype containing the rs7582694-C and rs7574865-T alleles were associated with a statistically increased type 1 AIH risk, OR $(95 \%$ CI $)=1.85(1.36-2.47),(P<0.001)$ (Table 5). But we did not find any haplotype combination in PTPN22 gene associated with type 1 AIH risk (Table 4).

\section{DISCUSSION}

In this study, we detected the impact of STAT4 and PTPN22 gene polymorphisms on type 1 AIH risk in Chinese Han children; we found that rs7574865 and rs7582694 in STAT4 gene minor alleles are associated with increased type 1 AIH risk, but rs2476601 in PTPN22 gene minor allele is associated with decreased type 1 AIH risk. However, we found that PTPN22- rs2488457 was not significantly associated with type 1 AIH risk after covariates adjustment. Although several studies [9, 10, 17] have reported the relationship between STAT4 and PTPN22 gene SNPs and some others autoimmune diseases, to date, less study focused on relation of STAT4 and PTPN22 gene polymorphisms and type 1 AIH risk previously, particularly for Chinese children. The current study was the second study to investigating the association between STAT4 gene polymorphisms and susceptibility to type-1 AIH. Previously Migita et al. [17] suggested that STAT4 polymorphism was positively associated type-1 AIH risk. STAT4 was one type of critical transcription factor involved in the Th1/Th2 cytokine balance regulation [18]. The association between STAT4 and some autoimmune diseases, including rheumatoid arthritis (RA) or systemic lupus erythematosus (SLE) has been reported in several previous studies [9, 10]. Taylor et al. [19] concluded that STAT4 polymorphism played an important role on susceptibility to SLE. Another two Japanese studies $[20,21]$ also suggested that STAT4 is a common autoimmune diseases related genetic risk factor, including RA and SLE. A recent meta- analysis [22, 23] demonstrated a significant association between rs7574865T allele within STAT4 gene and susceptibility to SLE, RA, T1D and so on. AIH pathogenesis were complex, study indicated that STAT4 represents a transcription factor, which involved in Th1 and Th17 differentiation [24]. STAT4 was an important genetic factor for IL-22 production, which plays a pathological role in IL-17dependent hepatitis [25].

In terms of PTPN22, although previous study has showed no significant association between PTPN22 and AIH [26], to date, just one study [16] have been performed on relationship with type 1 AIH risk, this study 
Table 1: General characteristics of 542 study participants in case and control group

\begin{tabular}{|c|c|c|c|}
\hline Variables & $\begin{array}{c}\text { Case group } \\
\quad(n=180)\end{array}$ & $\begin{array}{c}\text { Normal group } \\
\quad(n=362)\end{array}$ & $p$-values \\
\hline Age (year) & $7.8 \pm 4.1$ & $8.3 \pm 3.7$ & 0.154 \\
\hline Girls, $N(\%)$ & $146(81.11)$ & $298(82.3)$ & 0.730 \\
\hline Total Bilirubin (mg/ml) & $3.87 \pm 4.14$ & & \\
\hline Albumin $(3.5-5.0 \mathrm{~g} / \mathrm{L})$ & $3.89 \pm 0.75$ & & \\
\hline $\operatorname{IgG}(870-1700 \mathrm{mg} / \mathrm{dl})$ & 3085 (2407-3875) & & \\
\hline IAIHG score & $16.4 \pm 2.3$ & & \\
\hline $\mathrm{SMA}, n(\%)$ & $102(56.7)$ & & \\
\hline $\mathrm{ANA}+(\geq 1: 40), N(\%)$ & $151(83.9)$ & & \\
\hline \multicolumn{4}{|l|}{ Baseline laboratory values } \\
\hline $\operatorname{AST}(<40 \mathrm{IU} / \mathrm{L})$ & $432.4 \pm 444.1$ & & \\
\hline $\operatorname{ALT}(<40 \mathrm{IU} / \mathrm{L})$ & $484.3 \pm 490.5$ & & \\
\hline $\operatorname{ALP}(<112 \mathrm{IU} / \mathrm{L})$ & $463.7 \pm 210.3$ & & \\
\hline
\end{tabular}

Note: Means \pm standard deviation for age, total Bilirubin, albumin and IAIHG score; Median (inter-quartile range) for IgG.

suggested that PTPN22 gene SNP play a protective role on AIH risk. rs2476601 in PTPN22 was a missense SNP, which has been known as a factor associated with several autoimmune diseases, including RA and SLE [12-14], but this functional SNP was not associated with these autoimmune diseases in other studies [27-29].

In this study, type $1 \mathrm{AIH}$ risk was influenced by both STAT4 and PTPN22 gene, so it is interesting to investigate the impact of gene-gene interaction between the two genes on type 1 AIH risk. We found a significant gene-gene interaction between rs7582694 and rs2476601, participants with GC or CC of rs7582694 and CC of rs2476601 genotype have the highest type $1 \mathrm{AIH}$ risk, compared to participants with GG of rs7582694 and CT or TT of rs2476601 genotype. To our knowledge this is the first study for investigating impact of interaction

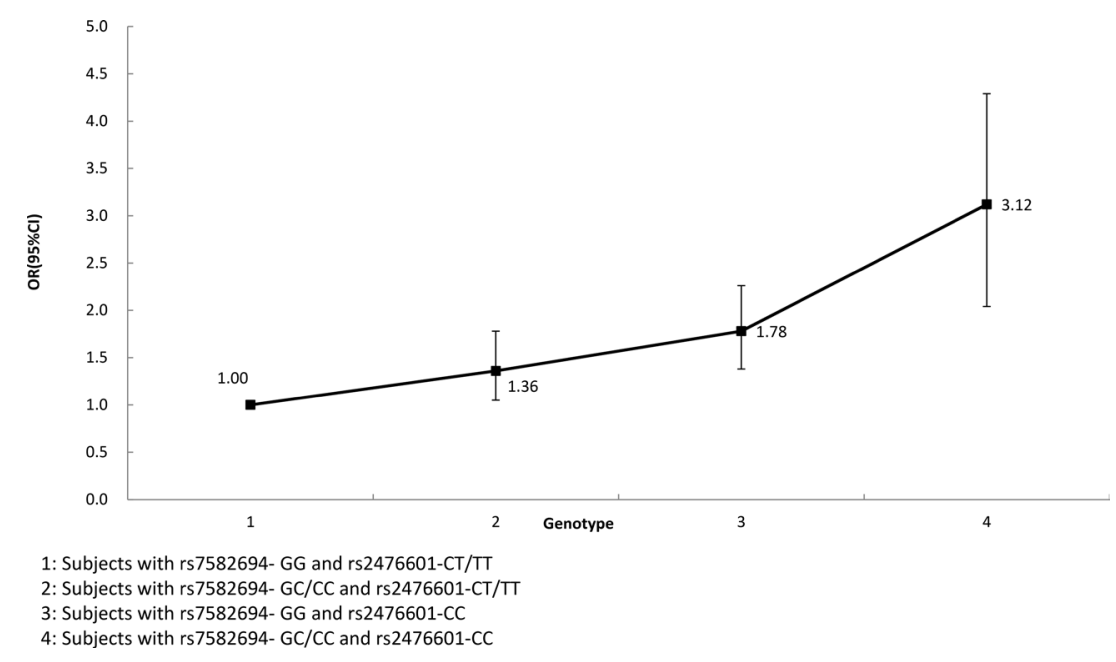

Figure 1: Interaction analysis for rs7582694 and rs2476601 by using logistic regression. 
Table 2: Genotype and allele frequencies of 4 SNPs between case and control group

\begin{tabular}{|c|c|c|c|c|c|c|}
\hline \multirow{2}{*}{ Gene/ SNP } & \multirow{2}{*}{$\begin{array}{c}\text { Genotypes and } \\
\text { Alleles }\end{array}$} & \multicolumn{2}{|c|}{ Frequencies N (\%) } & \multirow{2}{*}{ OR $(95 \% \text { CI })^{*}$} & \multirow{2}{*}{$P$-values } & \multirow{2}{*}{$\begin{array}{l}P \text { - values for HWE } \\
\text { test in controls }\end{array}$} \\
\hline & & Case $(n=180)$ & Control $(n=362)$ & & & \\
\hline \multicolumn{7}{|l|}{ STAT4 gene } \\
\hline \multirow[t]{8}{*}{ rs7574865 } & Co-dominant & & & & & \\
\hline & GG & $89(49.4)$ & $237(65.5)$ & 1.00 & & 0.622 \\
\hline & GT & $72(40.0)$ & $110(30.4)$ & $1.56(1.24-1.87)$ & $<0.001$ & \\
\hline & $\mathrm{TT}$ & $19(10.6)$ & $15(4.1)$ & $2.13(1.46-2.97)$ & $<0.001$ & \\
\hline & Dominant & & & & & \\
\hline & GG & $89(49.4)$ & $237(65.5)$ & 1.00 & & \\
\hline & $\mathrm{GT}+\mathrm{TT}$ & $180(50.6)$ & $125(34.5)$ & $1.63(1.28-1.98)$ & $<0.001$ & \\
\hline & Allele, T (\%) & $110(30.6)$ & $140(19.3)$ & & & \\
\hline \multicolumn{7}{|l|}{ rs7582694 } \\
\hline & Co-dominant & & & & & \\
\hline & GG & $84(46.7)$ & $232(64.1)$ & 1.00 & & 0.875 \\
\hline & $\mathrm{GC}$ & $75(41.7)$ & $115(31.8)$ & $1.64(1.31-2.04)$ & $<0.001$ & \\
\hline & $\mathrm{CC}$ & $21(11.7)$ & $15(4.1)$ & $2.21(1.68-2.92)$ & $<0.001$ & \\
\hline & Dominant & & & & & \\
\hline & GG & $84(46.7)$ & $232(64.1)$ & 1.00 & & \\
\hline & $\mathrm{GC}+\mathrm{C}$ & $96(53.3)$ & $130(35.9)$ & $1.73(1.38-2.19)$ & $<0.001$ & \\
\hline & Allele, C (\%) & $117(32.5)$ & $145(20.0)$ & & & \\
\hline \multicolumn{7}{|l|}{ PTPN22 gene } \\
\hline \multirow[t]{8}{*}{ rs2488457 } & Co- dominant & & & & & \\
\hline & GG & $105(58.4)$ & $192(53.0)$ & 1.00 & & 0.958 \\
\hline & $\mathrm{GC}$ & $65(36.1)$ & $143(39.5)$ & $0.85(0.57-1.19)$ & 0.528 & \\
\hline & $\mathrm{CC}$ & $10(5.6)$ & $27(7.5)$ & $0.77(0.52-1.23)$ & 0.476 & \\
\hline & Dominant & & & & & \\
\hline & GG & $105(58.4)$ & $192(53.0)$ & 1.00 & & \\
\hline & $\mathrm{GC}+\mathrm{C}$ & $75(41.7)$ & $170(47.0)$ & $0.83(0.44-1.20)$ & 0.507 & \\
\hline & Allele, C (\%) & 85 (23.6) & $197(27.2)$ & & & \\
\hline \multirow[t]{8}{*}{ rs2476601 } & Co-dominant & & & & & \\
\hline & $\mathrm{CC}$ & $118(65.6)$ & $184(50.8)$ & 1.00 & & 0.105 \\
\hline & $\mathrm{CT}$ & $53(29.4)$ & $139(38.4)$ & $0.68(0.47-0.93)$ & 0.002 & \\
\hline & $\mathrm{TT}$ & $9(5.0)$ & $39(10.8)$ & $0.56(0.26-0.91)$ & $<0.001$ & \\
\hline & Dominant & & & & & \\
\hline & $\mathrm{CC}$ & $118(65.6)$ & $184(50.8)$ & & & \\
\hline & $\mathrm{CT}+\mathrm{TT}$ & $62(34.4)$ & $178(49.2)$ & $0.65(0.44-0.93)$ & $<0.001$ & \\
\hline & Allele, T (\%) & $71(19.7)$ & $217(30.0)$ & & & \\
\hline
\end{tabular}

${ }^{*}$ Adjusted for gender and age. Bonferroni correction threshold: $P c<0.0083$. 
Table 3: GMDR investigation on gene-gene interactions within STAT4 and PTPN22 gene

\begin{tabular}{clccc}
\hline Locus no. & \multicolumn{1}{c}{ Best combination } & $\begin{array}{c}\text { Cross-validation } \\
\text { consistency }\end{array}$ & $\begin{array}{c}\text { Testing } \\
\text { accuracy }\end{array}$ & p-values $^{*}$ \\
\hline 2 & rs7582694 rs2476601 & $10 / 10$ & 0.6072 & 0.0100 \\
3 & rs7582694 rs2476601 rs7574865 & $8 / 10$ & 0.5399 & 0.1719 \\
4 & rs7582694 rs2476601 rs7574865 rs2488457 & $7 / 10$ & 0.4958 & 0.3770 \\
\hline
\end{tabular}

*Adjusted for gender and age.

Table 4: Haplotype analysis on association between STAT4 gene and type 1 AIH risk

\begin{tabular}{|c|c|c|c|c|c|c|}
\hline \multirow{2}{*}{ Haplotypes } & \multirow{2}{*}{ rs7582694 } & \multirow{2}{*}{ rs7574865 } & \multicolumn{2}{|c|}{ Frequencies } & \multirow{2}{*}{ OR $(95 \% C I)$} & \multirow{2}{*}{$p$-values* } \\
\hline & & & Case group & Control group & & \\
\hline $\mathrm{H} 1$ & G & G & 0.4732 & 0.5547 & 1.00 & - \\
\hline $\mathrm{H} 2$ & $\mathrm{C}$ & G & 0.2236 & 0.2128 & $1.14(0.82-1.64)$ & 0.592 \\
\hline H3 & $\mathrm{G}$ & $\mathrm{T}$ & 0.1935 & 0.1853 & $1.28(0.91-1.76)$ & 0.602 \\
\hline $\mathrm{H} 4$ & $\mathrm{C}$ & $\mathrm{T}$ & 0.1097 & 0.0472 & $1.85(1.36-2.47)$ & $<0.001$ \\
\hline
\end{tabular}

*Adjusted for gender and age. Bonferroni correction threshold: $P c<0.0125$.

between STAT4 and PTPN22 gene on type 1 AIH risk in Chinese population. The underlying mechanisms for this interaction may due to that both SNP were associated with AIH or other autoimmune diseases. We also conducted haplotype analysis in STAT4 and PTPN22 gene respectively. We found that haplotype containing the rs7582694-C and rs7574866-T alleles within STAT4 gene were associated with a statistically increased type 1 $\mathrm{AIH}$ risk. But we did not find any haplotype combination within PTPN22 gene associated with type 1 AIH risk.

The current study also has some limitations. Firstly, limited number of SNP in STAT4 and PTPN22 gene are included in current study, and in the future, more SNPs should be included in analysis. Secondly, some environment risk factors should be included in the gene-environment interaction analysis. In addition, the selection bias existed in the participant inclusion and exclusion, so the frequency for the $\mathrm{T}$ allele of rs 2476601 was higher than that in HapMap data. Thirdly, the results obtained in current study should be checked in other populations, for example, the gender and race difference of this relationship. Lastly, we do not resolve the question of STAT4 SNPs and AIH, Which SNP is dominant or is this purely a haplotype association because of strong LD.

In conclusion, the results of current study indicated that rs7574865 and rs7582694 in STAT4 gene minor alleles, interaction between rs 7582694 and rs2476601, and haplotype containing the rs7582694-C and rs7574865-T alleles are associated with increased type 1 AIH risk, but rs2476601 in PTPN22 gene minor allele is associated with decreased type 1 AIH risk.

\section{MATERIALS AND METHODS}

\section{Study population}

All participants in this study are consecutively recruited between January 2008 and November 2015 from the Third Affiliated Hospital of Sun Yat-sen University. All AIH patients had been diagnosed according to the scoring system of the International Autoimmune Hepatitis Group [30] and were classified as having type $1 \mathrm{AIH}$ based on antibody profiles. Those patients with clinical evidence of cholangitis or non-alcoholic steatohepatitis, positive for hepatitis B virus (HBV)-surface antigen (HBsAg) or hepatitis $\mathrm{C}$ virus (HCV)-RNA, and with other causes of liver disease were excluded from the study, controls are those who are free of liver related diseases and matched by sex, age and ethnic background in the same regions and nearly 1:2 matched to cases on the basis of age ( \pm 3 years), and control participants with other immune diseases were excluded. At last, a total of 542 participants (98 boys, 444 girls) consist of 180 AIH patients and 362 normal participants were included in this study (Figure 2). The mean age of all participants is $8.1 \pm 3.9$ years. The racial background of all individuals was Chinese Han. Data on demographic information, lifestyle and history of disease for all participants were obtained using a questionnaire administered by trained staffs, including data included 
Table 5: Description and Primer sequences for 4 SNPs used for PCR analysis

\begin{tabular}{|c|c|c|c|c|c|}
\hline SNP ID & Chromosome & $\begin{array}{l}\text { Functional } \\
\text { Consequence }\end{array}$ & $\begin{array}{l}\text { Major/ } \\
\text { minor }\end{array}$ & $\begin{array}{l}\text { Restriction } \\
\text { enzyme }\end{array}$ & Primers sequence \\
\hline \multicolumn{6}{|l|}{ STAT4 gene } \\
\hline rs 7574865 & 2:191099907 & Intron variant & $\mathrm{G} / \mathrm{T}$ & HpaI & $\begin{array}{l}\text { F: } \\
\text { 5'-AAAGAAGTGGGATAAAAAGAAGTTTG-3' } \\
\text { R: 5'-CCACTGAAATAAGATAACCACTGT-3' }\end{array}$ \\
\hline rs7582694 & $2: 191105394$ & Intron variant & $\mathrm{G} / \mathrm{C}$ & НруСН4III & $\begin{array}{l}\text { F: 5'-ATCCAACTCTTCTCAGCCCTT-3' } \\
\text { R: 5'-TCATAATCAGGAGAGAGGAGT-3' }\end{array}$ \\
\hline \multicolumn{6}{|c|}{ PTPN22 gene } \\
\hline rs2488457 & 1:113872746 & $\begin{array}{l}\text { Intron } \\
\text { variant, } \\
\text { upstream } \\
\text { variant } 2 \mathrm{~KB}\end{array}$ & $\mathrm{G} / \mathrm{C}$ & SacI & $\begin{array}{l}\text { F: 5'-CCATTGAGAGGTTATGCGAGCT-3' } \\
\text { R: 5'-CGCCACCTTGCTGACAACAT-3' }\end{array}$ \\
\hline rs2476601 & 1:113834946 & $\begin{array}{l}\text { Intron } \\
\text { variant, } \\
\text { missense }\end{array}$ & $\mathrm{C} / \mathrm{T}$ & $\mathrm{Xcm} I$ & $\begin{array}{l}\text { F: 5'-CCAGCTTCCTCAACCACAATAAATG-3' } \\
\text { R: 5'-CAACTGCTCCAAGGATAGATGATGA-3' }\end{array}$ \\
\hline
\end{tabular}

coexisting autoimmune diseases, serum levels of alkaline phosphatase and bilirubin and serum levels of ALT, AST and so on. Both anti-nuclear antibodies (ANA) and antismooth muscle antibodies (ASMA) were measured by indirect immunofluorescence on HEp-2 cells and cut-off titers for positivity were 1:40. Written informed consent was obtained from all participants. The protocol of this study was approved by the Ethics Committee of the Third Affiliated Hospital of Sun Yat-sen University.

\section{Genomic DNA extraction and genotyping}

We selected SNPs within the STAT4 and PTPN22 gene according to the following methods, including: 1) which have been reported associations with autoimmune diseases or risk factors of AIH; 2) minor allele frequency (MAF) greater than 5\%. Taking into account the limitations of human, material and financial resources, a total of two SNPs of STAT4 gene and two SNPs of PTPN22 gene were selected for genotyping in the study: rs7582694 and rs7574865 within STAT4, rs2476601 and rs2488457 within PTPN22. Genomic DNA is extracted from EDTA-treated whole blood, using the DNA Blood Mini Kit (Qiagen, Hilden, Germany) according to the manufacturer's instructions. The four SNPs were determined by the polymerase chain reaction-restriction fragment length polymorphism (PCR-RFLP) method [31]. PCR primer sequences for each polymorphism are shown in Table 5. The PCR reactions were carried out in a final volume of $20 \mu \mathrm{l}$ containing: $10 \times$ PCR buffer,

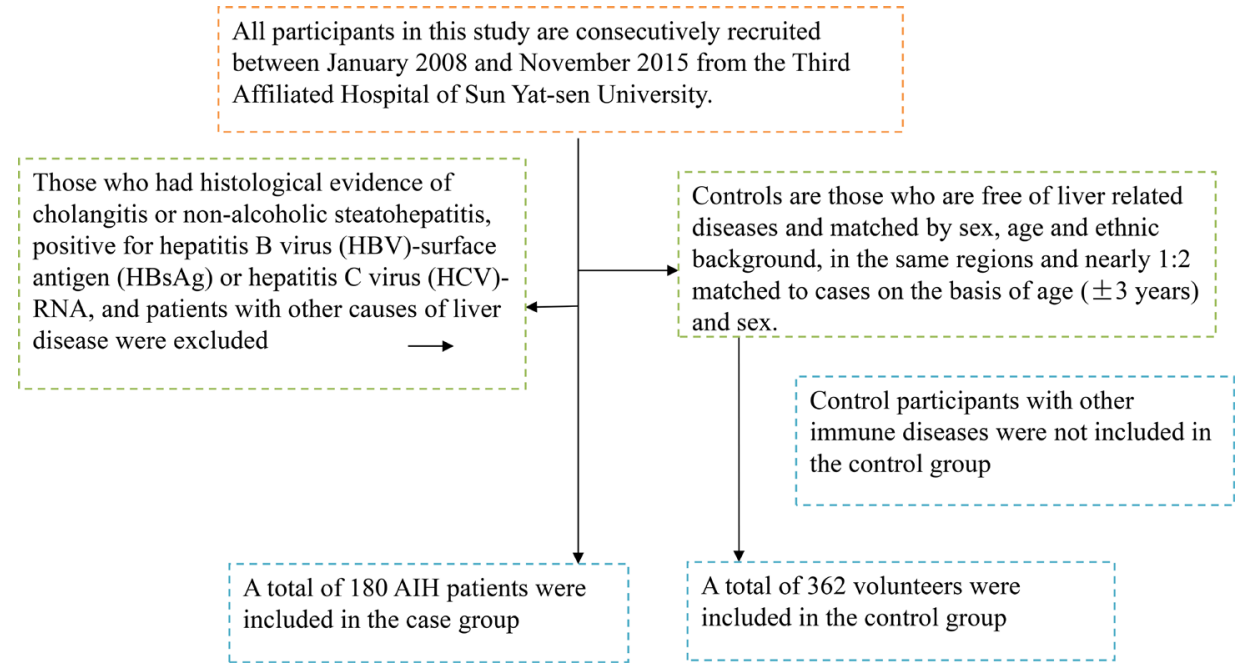

Figure 2: A flowchart on study population selection and exclusion. 
$4.5 \mathrm{mMMgCl}_{2}$ (Roche, Germany), $0.4 \mathrm{mM}$ of each dNTP (Fermentas, Germany), 10 pmol of each primer, 32 ng template DNA, 1 U Taq DNA polymerase (Roche, Germany) and sterile distilled water up to $20 \mu$ l.

For the two SNPs within STAT4 gene, rs 7574865 was a 147-bp PCR product and was digested with restriction enzyme and electrophoresed on a $2.5 \%$ polyacrylamide gel. Rs 7574865 was a 338-bp PCR product was digested with restriction enzyme and electrophoresed on a $3.0 \%$ polyacrylamide gel. For the two SNPs within PTPN22 gene, the PCR products were incubated with restriction enzymes for 1 or 16 hours. $4 \%$ agarose gel with Gold View (SBS Genentech, Beijing, China) was used to visualize the obtained digestion products. $20 \%$ of PCR-amplified DNA samples were examined by direct sequencing to confirm the genotyping results, which was $100 \%$ concordant. Amplification conditions started with an initial denaturation step of $6 \mathrm{~min}$ at $94^{\circ} \mathrm{C}$, followed by 35 cycles of $40 \mathrm{~s}$ denaturation $\left(94^{\circ} \mathrm{C}\right), 30 \mathrm{~s}$ annealing $\left(56^{\circ} \mathrm{C}\right)$ and $40 \mathrm{~s}$ extension $\left(72^{\circ} \mathrm{C}\right)$, ended by a final extension for $5 \mathrm{~min}\left(72^{\circ} \mathrm{C}\right)$.

\section{Statistical analysis}

The means and standard deviations (SDs) were calculated for normally distributed continuous variables and were analyzed using Student's $t$ test or one-way analysis of variance. Percentages were calculated for categorical variables and were analyzed using $\chi^{2}$ test. Departure from Hardy-Weinberg equilibrium (HWE) in cases and controls was tested using Pearson $\chi^{2}$ goodnessof-fit test. Haplotype analysis and Pairwise LD analysis were investigated by using SNPStats (available online at http://bioinfo.iconcologia.net/SNPstats). Logistic regression was performed to investigate association between SNPs within STAT4 and PTPN22 gene and susceptibility to type $1 \mathrm{AIH}$. Bonferroni correction was applied in case of multiple comparisons using the formula $p c=p / n(p c$ represents corrected value where $n$ is the number of comparisons made). Generalized multifactor dimensionality reduction (GMDR) [32] was used to screen the best interaction combinations among the 4 SNPs, some parameters such as cross-validation consistency, the testing balanced accuracy, and the sign test were calculated. Permutation testing is also conducted to gain empirical $P$ values of prediction accuracy as a benchmark based on 10,000 shuffles. A sign test or a permutation test (providing empirical $p$-values) for prediction accuracy can be used to measure the significance of an identified model.

\section{ACKNOWLEDGMENTS}

The writing of this paper is supported by the Third Affiliated Hospital of Sun Yat-sen University. We thank all the partners and staffs who help us in the process of this study.

\section{CONFLICTS OF INTEREST}

There is no conflicts of interest.

\section{FUNDING}

Science and Technology Projects Foundation of Guangdong Province (Grant No. 2014A020212120).

\section{REFERENCES}

1. Czaja AJ, Manns MP. Advances in the diagnosis, pathogenesis, and management of autoimmune hepatitis. Gastroenterology. 2010; 139:58-72.

2. Deneau M, Jensen MK, Holmen J, Williams MS, Book LS, Guthery SL. Primary sclerosing cholangitis, autoimmune hepatitis, and overlap in Utah children: epidemiology and natural history. Hepatology. 2013; 58:1392-1400.

3. Woynarowski M, Wozniak M, Pawlowska M, Lebensztejn D, Socha J, ChlebcewiczSzuba W, Chmurska-Motyka T, Czaja-Bulsa G, Gorczyca A, Iwanczak B, Korczowski B, Kuydowicz G, Liberek A, et al. Autoimmune hepatitis in Polish children: healthcare facilities, epidemiology, and standards of care assessed by a pediatric autoimmune hepatitis group. Exp Clin Hepatol. 2008; 4:66-70.

4. Gregorio GV, Portmann B, Reid F, Donaldson PT, Doherty DG, McCartney M, Mowat AP, Vergani D, MieliVergani G. Autoimmune hepatitis in childhood: a 20-year experience. Hepatology. 1997; 25:541-7.

5. Longhi MS, Ma Y, Mieli-Vergani G, Vergani D. Aetiopathogenesis of autoimmune hepatitis. J Autoimmun. 2010; 34:7-14.

6. Seki T, Ota M, Furuta S, Fukushima H, Kondo T, Hino K, Mizuki N, Ando A, Tsuji K, Inoko H, Kiyosawa K. HLA class II molecules and autoimmune hepatitis susceptibility in Japanese patients. Gastroenterology. 1992; 103:1041-47.

7. Umemura $T$, Katsuyama $Y$, Yoshizawa $K$, Kimura $T$, Joshita S, Komatsu M, Matsumoto A, Tanaka E, Ota M. Human leukocyte antigen class II haplotypes affect clinical characteristics and progression of type 1 autoimmune hepatitis in Japan. PLoS One. 2014; 9:e100565.

8. Kaplan MH. STAT4: a critical regulator of inflammation in vivo. Immunol Res. 2005; 31:231-42.

9. Remmers EF, Plenge RM, Lee AT, Graham RR, Hom G, Behrens TW, de Bakker PI, Le JM, Lee HS, Batliwalla F. STAT4 and the risk of rheumatoid arthritis and systemic lupus erythematosus. N Engl J Med. 2007; 357:977-86.

10. Sugiura T, Kawaguchi Y, Goto K, Hayashi Y, Tsuburaya R, Furuya T, Gono T, Nishino I, Yamanaka H. Positive association between STAT4 polymorphisms and polymyositis/ derma- tomyositis in a Japanese population. Ann Rheum Dis. 2012; 71:1646-50.

11. Gao B. Cytokines, STATs and liver disease. Cell Mol Immunol. 2005; 2:92-100. 
12. Begovich AB, Carlton VE, Honigberg LA, Schrodi SJ, Chokkalingam AP, Alexander HC, Ardlie KG, Huang Q, Smith AM, Spoerke JM, Conn MT, Chang M, Chang SY, et al. A missense single-nucleotide polymorphism in a gene encoding a protein tyrosine phosphatase (PTPN22) is associated with rheumatoid arthritis. Am J Hum Genet. 2004; 75:330-7.

13. Hinks A, Barton A, John S, Bruce I, Hawkins C, Griffiths CE, Donn R, Thomson W, Silman A, Worthington J. Association between the PTPN22 gene and rheumatoid arthritis and juvenile idiopathic arthritis in a UK population: further support that PTPN22 is an autoimmunity gene. Arthritis Rheum. 2005; 52:1694-9.

14. Orozco G, Sánchez E, González-Gay MA, LópezNevot MA, Torres B, Cáliz R, Ortego-Centeno N, JiménezAlonso J. Association of a functional single-nucleotide polymorphism of PTPN22, encoding lymphoid protein phosphatase, with rheumatoid arthritis and systemic lupus erythematosus. Arthritis Rheum. 2005; 52:219-24.

15. Orrú V, Tsai SJ, Rueda B, Fiorillo E, Stanford SM, Dasgupta J, Hartiala J, Zhao L, Ortego-Centeno N, D'Alfonso S, Italian Collaborative Group, Arnett FC, Wu H, et al. A loss-of-function variant of PTPN22 is associated with reduced risk of systemic lupus erythematosus. Hum Mol Genet. 2009; 18:569-79.

16. Umemura T, Joshita S, Yamazaki T, Komatsu M, Katsuyama Y, Yoshizawa K, Tanaka E, Ota M. Genetic Association of PTPN22 Polymorphisms with Autoimmune Hepatitis and Primary Biliary Cholangitis in Japan. Sci Rep. 2016; 6:29770.

17. Alvarez F, Berg PA, Bianchi FB, Bianchi L, Burroughs AK, Cancado EL, Chapman RW, Cooksley WG, Czaja AJ. International Autoimmune Hepatitis Group Report: review of criteria for diagnosis of autoimmune hepatitis. J Hepatol. 1999; 31:929-38.

18. Piotrowski P, Lianeri M, Wudarski M, Olesinska M, Jagodziński PP. Contribution of STAT4 gene singlenucleotide polymorphism to systemic lupus erythematosus in the Polish population. Mol Biol Rep. 2012; 39:8861-6.

19. Lou XY, Chen GB, Yan L, Ma JZ, Zhu J, Elston RC, $\mathrm{Li}$ MD. A generalized combinatorial approach for detecting gene-by gene and gene-by- environment interactions with application to nicotine dependence. Am J Hum Genet. 2007; 80:1125-37.

20. Kobayashi S, Ikari K, Kaneko H, Kochi Y, Yamamoto K, Shimane K, Nakamura Y, Toyama Y, Mochizuki T, Tsukahara S. Association of STAT4 with susceptibility to rheumatoid arthritis and systemic lupus erythematosus in the Japanese population. Arthritis Rheum. 2008; 58:1940-6.

21. Namjou B, Sestak AL, Armstrong DL, Zidovetzki R, Kelly JA, Jacob N, Ciobanu V, Kaufman KM, Ojwang JO, Ziegler J, Quismorio FP Jr, Reiff A, Myones BL, et al. Highdensity genotyping of STAT4 reveals multiple haplotypic associations with systemic lupus erythematosus in different racial groups. Arthritis Rheum. 2009; 60:1085-95.

22. Liang YL, Wu H, Shen X, Li PQ, Yang XQ, Liang L, Tian WH, Zhang LF, Xie XD. Association of STAT4 rs7574865 polymorphism with autoimmune diseases: a meta-analysis. Mol Biol Rep. 2012; 39:8873-82.

23. Tong G, Zhang X, Tong W, Liu Y. Association between polymorphism in STAT4 gene and risk of rheumatoid arthritis: a meta-analysis. Hum Immunol. 2013; 74:586-92.

24. Murphy KM, Ouyang W, Szabo SJ, Jacobson NG, Guler ML, Gorham JD, Gubler U, Murphy TL. T helper differentiation proceeds through Stat1-dependent, Stat4dependent and Stat4-independent phases. Curr Top Microbiol Immunol. 1999; 238:13-26.

25. Xu M, Morishima N, Mizoguchi I, Chiba Y, Fujita K, Kuroda M, Iwakura Y, Cua DJ, Yasutomo K, Mizuguchi J, Yoshimoto T. Regulation of the development of acute hepatitis by IL-23 through IL-22 and IL-17 production. Eur J Immunol. 2011; 41:2828-39.

26. de Boer YS, van Gerven NM, Zwiers A, Verwer BJ, van Hoek B, van Erpecum KJ, Beuers U, van Buuren HR, Drenth JP, den Ouden JW, Verdonk RC, Koek GH, Brouwer JT, et al. Dutch Autoimmune Hepatitis Study Group; LifeLines Cohort Study; Study of Health in Pomerania. Genome-wide association study identifies variants associated with autoimmune hepatitis type 1. Gastroenterology. 2014; 147:443-52.e5.

27. Ban Y, Tozaki T, Taniyama M, Tomita M, Ban Y. The codon 620 single nucleotide polymorphism of the protein tyrosine phosphatase-22 gene does not contribute to autoimmune thyroid disease susceptibility in the Japanese. Thyroid. $2005 ; 15: 1115-8$.

28. Ikari K, Momohara S, Inoue E, Tomatsu T, Hara M, Yamanaka H, Kamatani N. Haplotype analysis revealed no association between the PTPN22 gene and RA in a Japanese population. Rheumatology (Oxford). 2006; 45:1345-8.

29. Kawasaki E, Awata T, Ikegami H, Kobayashi T, Maruyama T, Nakanishi K, Shimada A, Uga M, Kurihara S, Kawabata Y, Tanaka S, Kanazawa Y, Lee I, et al. Systematic search for single nucleotide polymorphisms in a lymphoid tyrosine phosphatase gene (PTPN22): association between a promoter polymorphism and type 1 diabetes in Asian populations. Am J Med Genet A. 2006; 140:586-93.

30. Migita K, Nakamura M, Abiru S, Jiuchi Y, Nagaoka S, Komori A, Hashimoto S, Bekki S, Yamasaki K, Komatsu T, Shimada M, Kouno H, Hijioka T, et al. Association of STAT4 Polymorphisms with Susceptibility to Type-1 Autoimmune Hepatitis in the Japanese Population. PLoS One. 2013; 8:e71382.

31. Watford WT, Hissong BD, Bream JH, Kanno Y, Muul L, O'Shea JJ. Signaling by IL-12 and IL-23 and the immunoregulatory roles of STAT4. Immunol Rev. 2004; 202:139-56.

32. Taylor KE, Remmers EF, Lee AT, Ortmann WA, Plenge RM, Tian C, Chung SA, Nititham J, Hom G, Kao AH, Demirci FY, Kamboh MI, Petri M, et al. Specificity of the STAT4 genetic association for severe disease manifestations of systemic lupus erythematosus. PLoS Genet. 2008; 4:e1000084. 